\title{
湤䈱
}

\section{水稲における登熟性の品種間差に関する研究 一形態形質との関係一}

\author{
塩津文隆 ${ }^{1)} \cdot$ 劉建 $^{1)} \cdot$ 辺嘉賓 ${ }^{1)} \cdot$ 豊田正範 $^{2)} \cdot$ 楠谷彰人 $^{2)}$ \\ (1) 愛媛大学大学院連合農学研究科, ${ }^{2)}$ 香川大学農学部)
}

\begin{abstract}
要旨：水稲における形態形質と登熟性との関倸を，中国㧍よび日本産の日本型品種と日印交雑型などの多収性品種を 用いて調査した，さらに，得られた結果を基に重回帰分析を行い，形態形質によって登熟性がどの程度評価できるか 検討した，形態形質との単相関関係を調べたところ，登熟歩合 $(\mathrm{R})$ は収量キャパシティや穂の構造に関わる形質と の関係が強く, 精籾比重 $(\mathrm{S})$ は乾物生産に関わる特性との相関が強かった。さらに調査した形態形質の中から, 1 穂籾数 $\left(\mathrm{X}_{1}\right)$, 穂首節間長 $\left(\mathrm{X}_{2}\right)$, 穂数 $\left(\mathrm{X}_{3}\right)$, 穂首節間直径 $\left(\mathrm{X}_{4}\right)$, 成熟期の止葉角度 $\left(\mathrm{X}_{5}\right)$ を選び, $\mathrm{R} に は \mathrm{X}_{1}$ と $\mathrm{X}_{2}$, $\mathrm{S}$ には $\mathrm{X}_{3}, \mathrm{X}_{4}$ および $\mathrm{X}_{5}$ をそれぞれ説明変数とする重回帰分析を行った。 その結果， $\mathrm{R}$ に対しては $0.584^{* * * *}, \mathrm{~S}$ に対 しては 0.539****重相関倸数が得られ，用いた形態形質によってそれぞれの品種間差の 30 35\%程度が説明できた. また， $\mathrm{R} に は \mathrm{X}_{1}$ と $\mathrm{X}_{2}$ が約 $9: 10, \mathrm{~S}$ には $\mathrm{X}_{3}, \mathrm{X}_{4}, \mathrm{X}_{5}$ が約 5:4:3 の割合で影響していると推測された。 これらより， 本試験で選んだ形態形質は，登熟性に関する初期段階での大まかな選抜指標として役立つものと判断した。 キーワード：形態形質，重回帰分析，水稲，精籾比重，選抜指標，登熟性，登熟歩合，品種間差.
\end{abstract}

著者ら（塩津ら 2006，2007）はこれまで，水稲の登熟性 を登熟歩合と精籾比重に分けて検討し，さらに両者の積を 登熟度（松島 1967，楠谷ら 1993，1999）として収量との 関係を解析してきた。その結果，印度型や日印交雑型の多 収性品種は籾数が多い反面, 登熟度に関しては, 精籾比重 は高いものの登熟歩合は従来の日本型品種より低いことを 認め, 収量性向上のためにこのまま籾数を増やしていけば, 増収効果は次第に聥減していくと推論した。これらょり, 多収性育種に打いては今後とも籾数の増加が必須である が, これに伴う増収効果の低下を食い止めるためには登熟 歩合と精籾比重の双方から登熟度の向上を考光る必要があ ると指摘した。ささらに，登熟歩合および精籾比重と収量内 容物, 収量キャパシティ, 炭水化物の転流, 維管束特性な どとの関係を調查し，これらの特性によって品種の登熟性 が評価できること，また，登熟歩合と精籾比重の品種間差 を決定する機構は異なることを報告した，なお，Ichii and Kuwada（1981）, Ichii（1984）, 小林（2004）は出穂期に刈 り取った後の再生量によっても品種の登熟性が評価できる と述べている. しかし, これらの調査には多くの時間と労 力, 機材を要するため, 実際の育種現場への応用は難しい. とくに, 選抜の初期段階では何万, 何千という個体や系統 を扱うため,この全てについて登熟歩合や精籾比重を実測 し，さらにこれらに関わる炭水化物や維管束，再生量など を調査することは容易ではない，また，個体選抜では 1 株, 系統選抜でも数株を対象に選抜を行うので, 例えば貯蔵炭 水化物や再生量を調查するために出穂期に刈り取ってしま うと, 次世代用の種子が確保できなくなる。したがって,
これらの特性を初期段階での選抜指標として用いることは 事実上不可能である。このため, 個体選抜や初期の系統選 抜では観察あるいは極く簡便な方法で，しかも非破壊的に 調査できる形態形質によって選抜をすすめるのが望まし い.

こうした観点から，楠谷・三分一（1990）は北海道品種 の形態形質と登熟性との関係を検討し, 止葉が直立した穂 数型で, かつ, 穂首節間長が短く 2 次枝梗籾の少ない夕イ プが北海道における冷温登熟性に関する理想型であること を明らかにした，さらに，その結果に基づいて実際の選抜 を行い, はくちょうもち，あきほ，などの登熟性に優れた 品種を育成している。 しかし, 暖地の品種あるいは印度型 や日印交雑型品種を対象に，これらの関係を調查した報告 はほとんどみられない.

そこで本試験では, 中国㧍よび日本暖地の日本型新旧品 種，アジア各国で育成された印度型や日印交雑型品種を含 む多数の品種を供試し, 形態形質と登熟性との関倸を検討 した，さらに，得られた結果を基に重回帰分析を行い，形 態形質による登熟性評価の可能性と限界について考察し た。

\section{材料と方法}

\section{1. 供試品種}

試験は 2005 年に香川大学農学部において, 第 1 表に示 した 70 品種・系統（以下, 品種）を供試して行った。供 試品種のうち，1２7 は中国産，28～55 は日本産の日本型 品種，56〜70 はアジア各国で多収を目的に育成された印 
第 1 表 供試品種の出穂期, 登熟歩合および精籾比重.

\begin{tabular}{|c|c|c|c|c|c|c|c|c|c|c|c|c|c|c|}
\hline 番号 & 品種名 & 出穂期 & $\mathrm{R}$ & $\mathrm{S}$ & 番号 & 品種名 & 出穂期 & $\mathrm{R}$ & $\mathrm{S}$ & 番号 & 品種名 & 出穂期 & $\mathrm{R}$ & $\mathrm{S}$ \\
\hline 1 & 中作 23 号 & $8 \cdot 19$ & 76.6 & 1.112 & 26 & 02-11-10 & $8 \cdot 18$ & 58.0 & 1.111 & 51 & ヒノヒカリ & $8 \cdot 27$ & 76.8 & 1.102 \\
\hline 2 & 中作 93 号 & $8 \cdot 16$ & 60.8 & 1.087 & 27 & 塩豊 47 & $8 \cdot 11$ & 64.1 & 1.120 & 52 & 農林 22 号 & $8 \cdot 24$ & 78.7 & 1.137 \\
\hline 3 & 早花 2 号 & $8 \cdot 11$ & 46.7 & 1.082 & 28 & フジミノリ & $8 \cdot 05$ & 79.8 & 1.120 & 53 & 神力 & $9 \cdot 06$ & 55.3 & 1.125 \\
\hline 4 & 津星 2 号 & $8 \cdot 20$ & 58.0 & 1.120 & 29 & レイメイ & $8 \cdot 05$ & 60.9 & 1.094 & 54 & 亀治 & $9 \cdot 02$ & 61.7 & 1.135 \\
\hline 5 & 津稲 1129 & $8 \cdot 09$ & 46.6 & 1.104 & 30 & アキヒカリ & $8 \cdot 05$ & 59.6 & 1.118 & 55 & 十石 & $9 \cdot 06$ & 75.2 & 1.136 \\
\hline 6 & 金穂 1 号 & $8 \cdot 14$ & 57.3 & 1.099 & 31 & トヨニシキ & $8 \cdot 08$ & 69.7 & 1.110 & 56 & 南京 11 号 & $8 \cdot 14$ & 46.1 & 1.107 \\
\hline 7 & 金穂 2 号 & $8 \cdot 17$ & 74.1 & 1.119 & 32 & ふくひびき & $8 \cdot 03$ & 76.1 & 1.127 & 57 & 揚稲 4 号 & $8 \cdot 31$ & 52.1 & 1.153 \\
\hline 8 & 墾優 2000 & $8 \cdot 16$ & 51.9 & 1.079 & 33 & はえぬき & $8 \cdot 10$ & 66.4 & 1.108 & 58 & 水原 405 号 & $8 \cdot 25$ & 65.4 & 1.146 \\
\hline 9 & 墾育 16 号 & $8 \cdot 17$ & 61.8 & 1.110 & 34 & 東山 38 号 & $8 \cdot 24$ & 76.8 & 1.127 & 59 & 密陽 23 号 & $8 \cdot 26$ & 48.8 & 1.134 \\
\hline 10 & 墾育 18 号 & $8 \cdot 17$ & 53.2 & 1.118 & 35 & キヌヒカリ & $8 \cdot 10$ & 69.7 & 1.102 & 60 & ホシユタカ & $9 \cdot 07$ & 78.4 & 1.145 \\
\hline 11 & 墾育 28 号 & $8 \cdot 16$ & 51.7 & 1.101 & 36 & おくひかり & $8 \cdot 16$ & 65.5 & 1.108 & 61 & アケノホシ & $8 \cdot 25$ & 50.3 & 1.101 \\
\hline 12 & 花育 13 号 & $8 \cdot 14$ & 63.8 & 1.099 & 37 & ホウネンワセ & $8 \cdot 06$ & 60.4 & 1.093 & 62 & タカナリ & $8 \cdot 25$ & 50.4 & 1.134 \\
\hline 13 & 金珠 1 号 & $8 \cdot 10$ & 61.1 & 1.112 & 38 & コシヒカリ & $8 \cdot 12$ & 55.8 & 1.088 & 63 & オオチカラ & $8 \cdot 18$ & 38.5 & 1.061 \\
\hline 14 & 津星 1 号 & $8 \cdot 17$ & 63.2 & 1.123 & 39 & こいごころ & $8 \cdot 24$ & 65.0 & 1.118 & 64 & 西海 198 号 & $8 \cdot 25$ & 49.1 & 1.149 \\
\hline 15 & $99-409 \mathrm{H}$ & $8 \cdot 17$ & 53.1 & 1.096 & 40 & ナギホ & $8 \cdot 28$ & 72.7 & 1.128 & 65 & 西海 214 号 & $9 \cdot 07$ & 58.3 & 1.136 \\
\hline 16 & 津籾 8340 & $8 \cdot 11$ & 69.0 & 1.109 & 41 & 金南風 & $8 \cdot 31$ & 66.9 & 1.131 & 66 & 北陸 147 号 & $8 \cdot 29$ & 57.1 & 1.128 \\
\hline 17 & 1613 & $8 \cdot 13$ & 74.2 & 1.111 & 42 & 中生新千本 & $8 \cdot 28$ & 71.1 & 1.132 & 67 & 北陸 172 号 & $8 \cdot 16$ & 55.2 & 1.121 \\
\hline 18 & 津籾 1187 & $8 \cdot 15$ & 47.2 & 1.100 & 43 & 日本晴 & $8 \cdot 19$ & 70.4 & 1.137 & 68 & IR2151-957-5-3 & $8 \cdot 27$ & 44.8 & 1.181 \\
\hline 19 & 墾育 9109 & $8 \cdot 16$ & 41.9 & 1.087 & 44 & 黄金晴 & $8 \cdot 19$ & 75.6 & 1.119 & 69 & IR-36 & $8 \cdot 24$ & 59.6 & 1.179 \\
\hline 20 & 9540 & $8 \cdot 17$ & 62.6 & 1.125 & 45 & 朝の光 & $8 \cdot 16$ & 76.4 & 1.118 & 70 & IR-8 & $9 \cdot 11$ & 66.3 & 1.178 \\
\hline 21 & 津稲 779 & $8 \cdot 15$ & 53.4 & 1.090 & 46 & オオセト & $8 \cdot 20$ & 61.6 & 1.105 & \multicolumn{2}{|c|}{ 中国品種平均 } & $8 \cdot 16 \mathrm{c}$ & $58.0 \mathrm{~b}$ & $1.107 \mathrm{c}$ \\
\hline 22 & 津原 11 & $8 \cdot 17$ & 61.4 & 1.139 & 47 & レイホウ & $9 \cdot 05$ & 68.1 & 1.144 & \multicolumn{2}{|c|}{ 日本品種平均 } & $8 \cdot 21 b$ & $69.2 \mathrm{a}$ & $1.122 \mathrm{~b}$ \\
\hline 23 & 津原 17 & $8 \cdot 17$ & 57.5 & 1.099 & 48 & 瑞豊 & $9 \cdot 14$ & 74.2 & 1.163 & \multicolumn{2}{|c|}{ 多収性品種平均 } & $8 \cdot 27 a$ & $54.7 \mathrm{~b}$ & $1.137 \mathrm{a}$ \\
\hline 24 & 津原 144 & $8 \cdot 26$ & 47.5 & 1.127 & 49 & ミナミニシキ & $9 \cdot 10$ & 68.3 & 1.142 & \multicolumn{2}{|c|}{ 全品種平均 } & $8 \cdot 20$ & 61.8 & 1.119 \\
\hline 25 & 02-103 & $8 \cdot 17$ & 50.7 & 1.112 & 50 & コガネマサリ & $8 \cdot 27$ & 78.6 & 1.141 & \multicolumn{2}{|c|}{ 変異係数（\%) } & 13.1 & 16.8 & 2.1 \\
\hline
\end{tabular}

$1 \sim 27$ : 中国品種, $28 \sim 55$ : 日本品種, $56 \sim 70$ : 多収性品種.

出穂期：(月・日), $\mathrm{R}$ : 登熟歩合 $(\%), \mathrm{S}$ : 精籾比重.

異なるアルファベット間には 5\% 水準で有意差があることを示す（Tukey－Kramer の HSD 検定）.

度型や日印交雑型などの品種である。そこで, 以下の本文 中ではそれぞれを中国品種, 日本品種, 多収性品種と総称 した.

\section{2. 栽培方法}

5 月 23 日に播種し 17 日間畑育苗した苗を，6月9日に 22.2 株 $\mathrm{m}^{-2}(30 \mathrm{~cm} \times 15 \mathrm{~cm}), 1$ 株 1 本植えで本田に手植 えした，肥料は $\mathrm{N}, \mathrm{P}_{2} \mathrm{O}_{5}, \mathrm{~K}_{2} \mathrm{O}$ を $10 \mathrm{a}$ 当たり $8.5 \mathrm{~kg}$ ずつ 全量基肥で施用した。試験は， 1 区当たり 26 株 2 条，各 品種 2 反復で行った。

\section{3. 調査方法}

各品種の出穂期に 10 株について茎数, 最長茎の草丈, 止葉の長さ (以下, 止葉長) と幅 (止葉幅) および傾斜角 度 (水平面からの立ちあがり角度. 止葉角度) を調査した。 さらに同じ止葉の中央部の葉色を葉緑素計 SPAD-502（ミ ノルタ社製）で測定した。その後, 生体重中庸の 4 株を選 んで部位別 (葉, 程 +葉鞘, 穂) に分け, 葉面積を測定す るとともに, $80^{\circ} \mathrm{C}$ で 48 時間通風乾燥させた後, それぞれ
の乾物重を秤量した。

出穂期後 3 週間目に 10 株を採取し, 生体重中庸の 4 株 につき長稈 2 茎の穂首節直下約 $1 \mathrm{~cm}$ のさ（長径と短径） をデジタルノギスで測定した。長径と短径の平均值を穂首 節間直径とした（塩津ら 2007）.

成熟期に 10 株について穂数を計数した後，その中の平 均穂数に近い 4 株を地際で刚取り, 各株中の長㷏 3 茥につ いて止葉角度, 止葉葉鞘長, 㷏長, 穂長, 穂首節間長, 1 次および 2 次枝梗数を調査した。その後, 出穂期と同様の 方法によって部位別乾物重を測定した。ささらに，4株分の 籾を対象に水道水による水選を行った. 水道水に沈んだ籾, すなわち比重 1.00 以上の籾を精籾とし，その数を全籾数 で除して登熟歩合を算出した（小松ら 1984）。沈下した籾

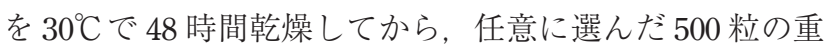
量と容積を津野ら（1990）の方法にしたがって測定し，精 籾 1000 粒重, 精籾 1000 粒容積, 精籾比重を求めた.

これらの調査值を基に, 草丈 $\times$ 茎数, 止葉長 $\times$ 止葉幅（止 葉面積), 止葉長 $\times$ 止葉幅 $\times$ 茥数 (株当たり止葉面積), 葉 面積指数 (LAI), 比葉重 (SLW), 草丈 $/$ 秙長比, 穂重 $/$ 全 
重比, 1 穂籾数/穂数（草型指数, 楠谷. 三分一 1990), 1 穂籾数 $/$ 穂長 (粒着密度), 1 穂籾数 $\times$ 精籾容積 $(1$ 穂籾容積 $)$ を算出した。

\section{結果}

\section{1. 気象経過}

第 1 図に, 実験戋場から北西約 $9 \mathrm{~km}$ にあ高松地方気象 台の 2005 年と平年（1995～2004 年の 10 年間の平均值）に おける 6 月上旬から 10 月下旬までの日平均気温と日積算 日射量を示した。 2005 年の気温は平年と比較して，6月中 は高く，7月上旬に $1.6^{\circ} \mathrm{C}, 8$ 月下旬に $1.0^{\circ} \mathrm{C}$ 低くなった ものの，全般的にはほぼ平年並みに推移した。日射量は， 6 月中は平年より多かったが, 7 月上旬には平年を $9.4 \mathrm{MJ} /$ $\mathrm{m}^{2}$ 下回った。 8 月下旬と 9 月上旬および 10 月上旬も平年 より $4.0 \mathrm{MJ} / \mathrm{m}^{2}$ 前後少なかったが, 他の時期はほとんど 平年並みであった。
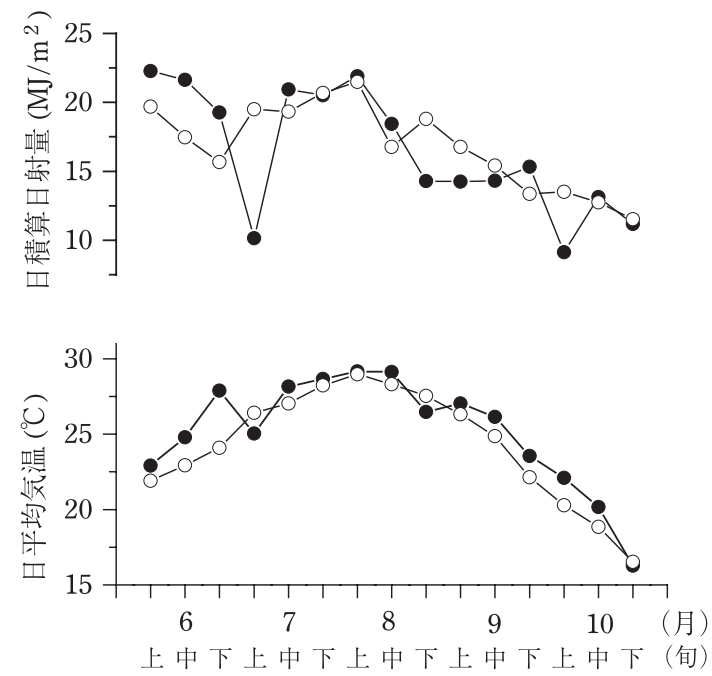

第 1 図気象経過.

○- $: 2005$ 年, $\bigcirc-\bigcirc:$ 平年（1995 2004 年の過去 10 年 間の平均値)。

\section{2. 出穂期, 登熟歩合および精籾比重}

第 1 表に，供試品種とそれぞれの出穂期，登熟歩合（R) および精籾比重（S）を示した，出穂期はふくひびきの 8 月 3 日が最も早く, 瑞豊の 9 月 14 日が最も遅く, 変異係 数は $13.1 \%$ であった。品種群別平均值でみると, 中国品 種は 8 月 16 日，日本品種は 8 月 21 日，多収性品種は 8 月 27 日となり，それぞれの間に有意差が認められた。 $\mathrm{R}$ はフ ジミノリの $79.8 \%$ が最も高かった。他に中作 23 号など合 計 17 品種が $70 \%$ 以上の高い值を示したが，その内訳は， 中国品種 3 , 日本品種 13 , 多収性品種 1 であった。最低は オオチカラの $38.5 \%$ であった。 中国品種と多収性品種の 中には $50 \%$ 以下のものがそれぞれ 5 品種あったが, 日本 品種の中に $50 \%$ 以下のものはなかった。このため, 品種 群別平均值は中国品種 $58.0 \%$ ，日本品種 $69.2 \%$, 多収性 品種 $54.7 \%$ となり，日本品種が中国品種および多収性品 種を有意に上回った。中国品種と多収性品種の平均值は中 国品種の方が高かったが，有意差は認められなかった， S は IR2151-957-5-3の 1.181 が最高，才オチカラの 1.061 が最低であった．品種群別の変異幅は中国品種 1.079 1. 139, 日本品種 $1.088 \sim 1.163$, 多収性品種 1.061 1. 181 であり，それぞれの平均值は $1.107 ， 1.122 ， 1.137$ で有 意差がみられ，多収性品種が最も高く，中国品種が最も低 かった

第 2 図は, 出穂迄日数 (HD) と $\mathrm{R}$ および $\mathrm{S}$ との関係を 示したものである. $\mathrm{HD}$ と $\mathrm{S}$ との間には $0.1 \%$ 水準で有意 な正の相関関係が認められたが, $\mathrm{HD}$ と R は無関係であっ た。

第 3 図には, $\mathrm{R}$ と S との関係を示した。両者の間には $5 \%$ 水準で有意な正の相関関係が存在し， Rが高い品種は $\mathrm{S} も$ 高いという傾向がみられたが，その関係はそれほど強いも のではなかった。

\section{3. 形態形質と登熟歩合および精籾比重との関係}

第 2 表に, 調査した形質と出穂迄日数 (HD), 登熟歩合 $(\mathrm{R})$ および精籾比重（S）との単相関係数および HD を固定し た場合の $\mathrm{R}, \mathrm{S}$ との偏相関係数を示した．項目番号の $1 \sim 6$
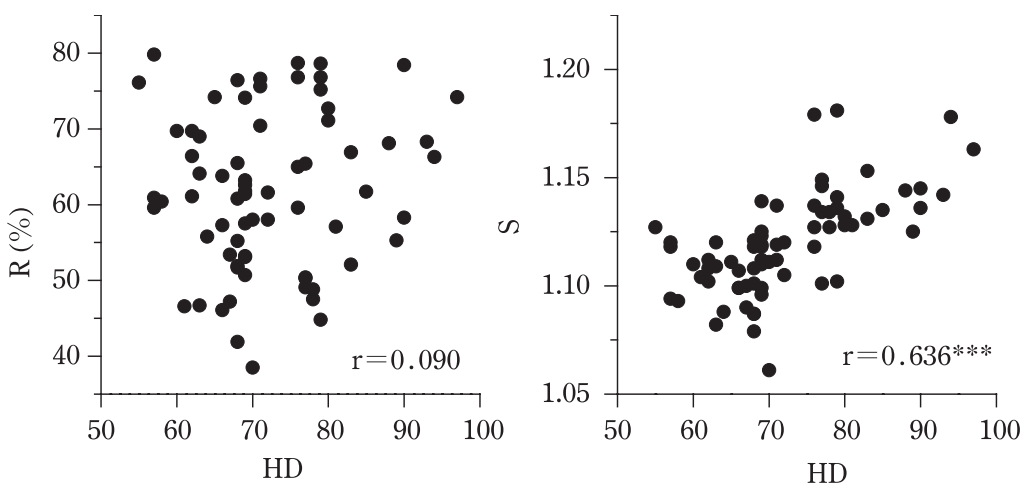

第 2 図 出穂迄日数（HD）と登熟歩合 $(\mathrm{R})$ および精籾比重（S）との関係. ***: $0.1 \%$ 水準で有意. 


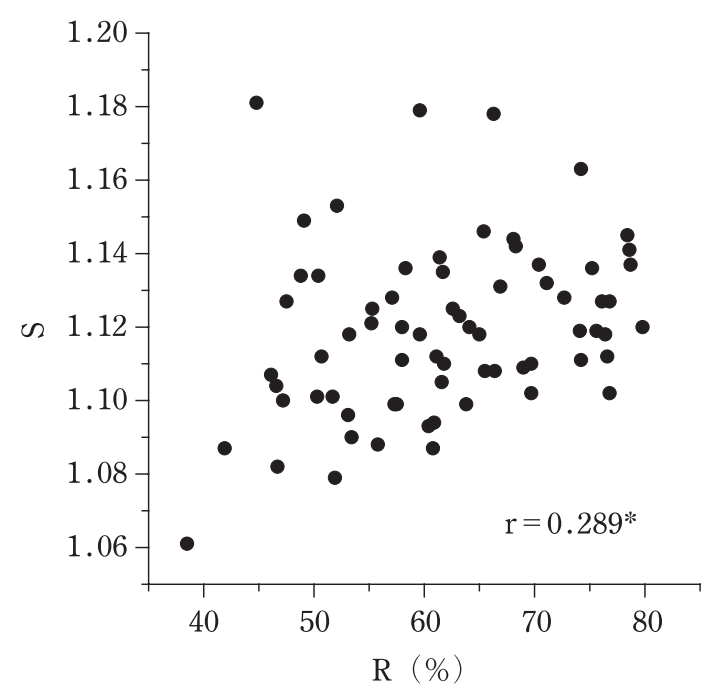

第 3 図 登熟歩合（R）と精籾比重（S）との関係. *: $5 \%$ 水準で有意.

は出穂期， 7 は出穂期後 3 週間目，8～18 は成熟期に実測 した形質であり，19〜26 は実測した形質間の乗除によって 求めた計算值，すなわち誘導形質（武田 1983）である. 27 〜30 は物質生産に関わる特性である。

HD は, 出穂期における乾物重と正, 出穂期の葉色, 2 次枝梗数, 穂重/全重比と負の $0.1 \%$ 水準で有意な相関を 示した。 また, 出穂期の葉面積指数 (LAI), 比葉重 (SLW), 成熟期における乾物重との間に正, 1 穂籾数, 粒着密度, 1 穂籾容積との間に負の $1 \%$ 水準で有意な相関関係が認め られた。

$\mathrm{R}$ および $\mathrm{S}$ との単相関係数が \pm 0.4 以上の值を示す形質 は少なかった。しかし， $\mathrm{R}$ は穂首節間長と正， 1 穂籾数， 2 次枝梗数および 1 穂籾容積と負の $0.1 \%$ 水準で有意な相関 を示した。また，稈長および草丈×茎数との間に正，穂首 節間直径, 草型指数および粒着密度との間に負の $1 \%$ 水準 で有意な相関関係が認められた。ささらに， $\mathrm{R}$ は止葉幅およ び 1 次枝梗数と負, 出穂期の茎数, 穂数掞よび成熟期の乾 物重と正の $5 \%$ 水準で有意な相関を示したが，（成熟期の乾 物重 - 出穂期の乾物重) / 総籵数との間にも $\mathrm{r}=0.354^{* * *}$ の $1 \%$ 水準で有意な正の相関関係が存在した (表略).この ように， $\mathrm{R} に は$ 収量キャパシティに関わる形質の影響が強 いという傾向がみられた。一方, S は乾物生産関連特性と の関係が強く, 出穂期の LAI および乾物重, 成熟期の乾物 重と $0.1 \%$ 水準で正の, 穂数および成熟期の止葉角度と正, 出穂期の葉色および穂重/全重比と負の $1 \%$ 水準で有意な 相関を示した。 その他では, 穂首節間直径, 草丈×茥数, 株当たり止葉面積および草丈/程長比との間に正，粒着密 度および 1 穂籾容積との間に負の $5 \%$ 水準で有意な相関関 係がみられた。このように， $\mathrm{R}$ と $\mathrm{S}$ はともに，穂数，草丈 $\times$ 茎数, 成熟期の乾物重と正, 粒着密度, 1 穂籾容積と負 の有意な相関を示したが, 穂首節間直径との単相関係数は $\mathrm{R}$ では負， $\mathrm{S}$ では正で有意であった。 なお，水稲の登熟に
は籾数や 1000 粒重も影響する。そこで，これらと登熟歩 合および精籾比重との関係を検討したところ，穂数 $\times 1$ 穂 籾数から求めた $\mathrm{m}^{2}$ 当たり総籵数は水原 405 号の 55365 粒 が最も多く，才オチカラの 20132 粒が最も少なかった（変 異係数: $17.9 \%$ ）が, 登熟歩合との単相関係数は $\mathrm{r}=$ -0.205 , 精籾比重との単相関係数は $\mathrm{r}=0.109$ でともに 有意性は認められなかった（図略）。また，精籾 1000 粒重 はオオチカラの $38.06 \mathrm{~g}$ が最も重く, ホシュタカの $18.69 \mathrm{~g}$ が最も軽かった（变異係数：10.5\%）が, 登熟歩 合および精籾比重との単相関係数は有意ではなかった（第 2 表).

$\mathrm{HD}$ を固定した場合の偏相関関係についてみると， R は $\mathrm{HD}$ と無関係であったので, 各形質と $\mathrm{R}$ との偏相関係数は 単相関係数とほとんど変わらなかった。しかし, S と HD との間には有意な正の相関関係が存在したため, 形質に よっては偏相関係数と単相関係数に大きな差がみられた。 すなわち, 出穂期の葉色, 粒着密度, 1 穂籾容積と S との 単相関係数は有意であったが, 偏相関係数に有意性は認め られなかった。また，出穂期および成熟期における乾物重 との偏相関係数も, 単相関係数に比べて低下した。逆に, 単相関係数が有意でなかった出穂期の止葉角度, 茎数, 止 葉面積およびSLW との偏相関係数には有意性が認められ た.

なお，数が多いため表では示せなかったが，形質間相互 の相関関係を検討したところ, 草丈, 止葉長, 稈長, 穂長, 止葉葉鞘長, 穂首節間長など茎の長さや茎上部の伸長性に 関わる形質の相互間, 出穂期の止葉角度と成熟期の止葉角 度との間, 出穂期の茥数と穂数との間, 1 穂籾数, 1 次枝 梗数, 2 次枝梗数, 草型指数, 粒着密度, 1 穂籾容積など の収量キャパシティや穂の構造に関わる形質の相互間, 出 穂期の乾物重と草丈，草丈 ×茎数，止葉長，株当たり止葉 面積, LAI, 秙長, 穂首節間長, 成熟期の乾物重の間など に強い正の相関関係が存在した. 一方, 出穂期の葉色と LAI や株当たり止葉面積および乾物重との間，穂数と 1 穂 籾数, 1 次枝梗数, 2 次枝梗数, 草型指数, 粒着密度, 1 穂 籾容積との間には強い負の相関関係が認められた。穂首節 間直径は 1 穂籾数と, 精籾 1000 粒重は精籾 1000 粒容積と 有意な正の相関を示したが，他にこれらと強い関係をもつ 形質はなかった。

\section{4. 重回帰分析}

第 2 表に示した 30 形質から代表的なものを取り上げ, これらを説明変数とする重回帰分析を行った。用いる形質 を選択するに当たっては, 登熟歩合 $(\mathrm{R})$ および精籾比重 $(\mathrm{S})$ との相関関係を重視するとともに, 調査が比較的容易であ ることを条件とした。 また，相互間に関係が深い形質群か らは， R や S との関係が特に強い形質を代表として選んだ。 さらに, 誘導形質は複数の形質から求めた計算值で遺伝子 的実体がはっきりしない（武田 1983）こと，乾物生産に関 
第 2 表 形態形質と出穂迄日数, 登熟歩合および精籾比重との相関係数.

\begin{tabular}{|c|c|c|c|c|}
\hline 番号 & 項目 & $\mathrm{HD}$ & $\mathrm{R}$ & $S$ \\
\hline 1 & 葉色 & $-0.575^{* * *}$ & $-0.196(-0.177)$ & $-0.320 * *(0.073)$ \\
\hline 2 & 草丈 & $0.242^{*}$ & $0.224(0.210)$ & $0.229(0.101)$ \\
\hline 3 & 止葉長 & -0.058 & $0.131(0.137)$ & $0.125(0.209)$ \\
\hline 4 & 止葉幅 & -0.177 & $-0.290 *(-0.280 *)$ & $-0.003(0.144)$ \\
\hline 5 & 止葉角度 & 0.007 & $0.161(0.161)$ & $0.234\left(0.298^{*}\right)$ \\
\hline 6 & 茎数 & 0.026 & $0.254^{*}\left(0.253^{*}\right)$ & $0.213\left(0.255^{*}\right)$ \\
\hline 7 & 穂首節間直径 & 0.026 & $-0.356 * *\left(-0.360^{* *}\right)$ & $0.295 *(0.361 * *)$ \\
\hline 8 & 程長 & 0.131 & $0.354 * *\left(0.346^{* *}\right)$ & $-0.008(-0.119)$ \\
\hline 9 & 穂長 & -0.048 & $-0.120(-0.116)$ & $0.134(0.213)$ \\
\hline 10 & 穂数 & $0.281^{*}$ & $0.277^{*}\left(0.263^{*}\right)$ & $0.337 * *(0.244 *)$ \\
\hline 11 & 1 穂籾数 & $-0.359^{* *}$ & $-0.418^{* * *}\left(-0.414^{* * *}\right)$ & $-0.197(0.043)$ \\
\hline 12 & 精籾 1000 粒重 & 0.032 & $-0.107(-0.110)$ & $-0.011(-0.041)$ \\
\hline 13 & 精籾 1000 粒容積 & -0.098 & $-0.209(-0.202)$ & $-0.209(-0.191)$ \\
\hline 14 & 止葉角度 & 0.121 & $0.202(0.193)$ & $0.348 * *\left(0.353^{* *}\right)$ \\
\hline 15 & 止葉葉鞘長 & 0.024 & $0.003(0.001)$ & $0.180(0.213)$ \\
\hline 16 & 穂首節間長 & -0.214 & $0.449 * * *(0.481 * * *)$ & $-0.103(0.045)$ \\
\hline 17 & 1 次枝梗数 & -0.134 & $-0.256^{*}\left(-0.247^{*}\right)$ & $-0.145(-0.079)$ \\
\hline 18 & 2 次枝梗数 & $-0.389^{* * *}$ & $-0.419^{* * *}\left(-0.419^{* * *}\right)$ & $-0.199(0.068)$ \\
\hline 19 & 草丈 $\times$ 茎数 & 0.130 & $0.338^{* *}\left(0.330^{* *}\right)$ & $0.296 *(0.279 *)$ \\
\hline 20 & 止葉面積 & -0.147 & $-0.075(-0.063)$ & $0.113\left(0.270^{*}\right)$ \\
\hline 21 & 株当たり止葉面積 & -0.150 & $0.146(0.162)$ & $0.236^{*}\left(0.434^{* * *}\right)$ \\
\hline 22 & 草丈/稈長比 & 0.106 & $-0.227(-0.239)$ & $0.273 *(0.268 *)$ \\
\hline 23 & 穂重/全重比 & $-0.767^{* * *}$ & $0.116\left(0.289^{*}\right)$ & $-0.358^{* *}\left(0.261^{*}\right)$ \\
\hline 24 & 草型指数 & $-0.304^{*}$ & $-0.372^{* *}\left(-0.363^{* *}\right)$ & $-0.228(-0.047)$ \\
\hline 25 & 粒着密度 & $-0.366^{* *}$ & $-0.351 * *(-0.343 * *)$ & $-0.305^{*}(-0.100)$ \\
\hline 26 & 1 穂籾容積 & $-0.372^{* *}$ & $-0.442^{* * *}\left(-0.441^{* * *}\right)$ & $-0.237 *(0.000)$ \\
\hline 27 & LAI（出穂期） & $0.319^{* *}$ & $0.136(0.114)$ & $0.429 * * *(0.309 * *)$ \\
\hline 28 & SLW（出穂期） & $0.351^{* *}$ & $-0.036(-0.072)$ & $0.037\left(-0.257^{*}\right)$ \\
\hline 29 & 出穂期の乾物重 & $0.616^{* * *}$ & $0.174(0.151)$ & $0.566^{* * *}\left(0.286^{*}\right)$ \\
\hline 30 & 成熟期の乾物重 & $0.353^{* *}$ & $0.282 *(0.269 *)$ & $0.442 * * *(0.301 *)$ \\
\hline
\end{tabular}

$\mathrm{HD}$ : 出穂迄日数, $\mathrm{R}$ : 登熟歩合, $\mathrm{S}$ : 精籾比重. 5 の止葉角度は出穂期, 14 の止葉角度は成熟期に 調査. LAI : 葉面積指数, SLW : 比葉重.

（）：出穂迄日数を固定した場合の偏相関係数.

*，**，***：それぞれ $5 \% ， 1 \% ， 0.1 \%$ 水準で有意.

第 3 表 重回帰分析に用いた形態形質の相互間相関係数.

\begin{tabular}{clcccc}
\hline 番号 & 項目 & 2 & 3 & 4 & 5 \\
\hline 1 & 1 穂籾数 & -0.104 & $-0.656^{* * *}$ & $0.516^{* * *}$ & -0.089 \\
2 & 穂首節間長 & & 0.124 & $-0.357^{* *}$ & 0.019 \\
3 & 穂数 & & & -0.204 & 0.137 \\
4 & 穂首節間直径 & & & $0.271^{*}$ \\
5 & 止葉角度 (成熟期) & & & \\
\hline$*, * *$ & $* * *$ それぞれ $5 \%, \quad 1 \%, 0.1 \%$ 水準で有意. & & \\
\end{tabular}

わる特性は調査に時間と手間がかかることから選択対象外 とした，この方針に従って，1 穂籾数，穂首節間長，穂数， 穂首節間直径，成熟期の止葉角度の 5 形質を選択した。 1 穂籾数は $\mathrm{R}$ との関係が強く, 2 次枝梗数や 1 穂籾容積とも 密接な正の相関を示したので,これらの代表として選んだ。
穂首節間長は, 草丈, 稈長, 穂長などと高い相関関係にあっ たが,これらの中では $\mathrm{R}$ との関係が最も強かったので取り 上げた，穂数と穂首節間直径は， $\mathrm{R}$ および $\mathrm{S}$ の双方と有意 な相関を示すとともに，穂数は草型に関わる重要な生態的 形質であり，穂首節間直径は維管束を通じて炭水化物の転 
第 4 表 登熟歩合と精籾比重に対する重回帰分析.

\begin{tabular}{llcc}
\hline & \multicolumn{1}{c}{ 重回帰式 } & 重相関係数 & 決定係数 \\
\hline 登熟歩合 & $\mathrm{Y}_{1}=-0.15 \mathrm{X}_{1}+0.87 \mathrm{X}_{2}+52.8$ & $0.584^{* * * *}$ & 0.341 \\
精籾比重 & $\mathrm{Y}_{2}=1.3 \times 10^{-4} \mathrm{X}_{3}+3.0 \times 10^{-5} \mathrm{X}_{4}+5.1 \times 10^{-4} \mathrm{X}_{5}+1.0$ & $0.539^{* * *}$ & 0.291 \\
\hline $\mathrm{Y}_{1}$ : 登熟歩合 $(\mathrm{R}), \mathrm{Y}_{2}:$ 精籾比重 $(\mathrm{S}), \mathrm{X}_{1}: 1$ 穂籾数, $\mathrm{X}_{2}$ : 穂首節間長, $\mathrm{X}_{3}$ : 穂数, $\mathrm{X}_{4}$ : 穂首節間直径, $\mathrm{X}_{5}$ : 成熟期の \\
止葉角度. \\
**** $: 0.1 \%$ 水準で有意.
\end{tabular}

流に影響する形質（塩津ら 2007）であるために選択した。 出穂期と成熟期に扔ける止葉角度には有意な正の相関関係 が認められ，S は双方と正の相関傾向を示したが，その関 係は成熟期の葉色との方が強かったので，こちらを代表形 質とした。 なお, 出穂期における葉色と $\mathrm{S}$ との単相関係数 は $1 \%$ 水準で有意であったが，HDを固定した場合の偏相 関係数に有意性は認められなかった。すなわち，葉色と $\mathrm{S}$ との間の有意な相関関係は品種の早晚性を介した間接的な ものと判断されたので, 葉色は説明変数として取り上げな かった。

第 3 表に，選択した 5 形質の相互間相関倸数を示した $\mathrm{R}$ との相関関係が有意であった 1 穂籾数, 穂首節間長, 穂数, 穂首節間直径のうち， 1 穂籾数と穂首節間長との関係に有 意性は認められなかったが，1穂籾数と穂数との間には負， 穂首節間直径との間には正の $0.1 \%$ 水準で有意な相関関係 が存在した，そこで，1穂籾数を一定とした場合の穂数抒 よび穂首節間直径と $\mathrm{R}$ との偏相関係数を求めたところ，そ れぞれ $\mathrm{r}=0.004, \mathrm{r}=-0.183$ となった（表略）。これら より，1 穂籾数が同じであれば，穂数掞よび穂首節間直径 は R に直接影響しないと判断した.このため Rについては， 1 穂籾数と穂首節間長だけを説明変数に用いることにした 一方，S と有意な相関を示した穂数，穂首節間直径，成熟 期の止葉角度の相互間相関係数は低かった。したがって, これらの間の遺伝的つながりは弱いと判断し， S に対して はこの 3 形質を説明変数とした

第 4 表は重回帰分析の結果，第 4 図は標準偏回帰係数比 から推定した各形質の寄与率を示したものである。1 穂籾 数 $\left(\mathrm{X}_{1}\right)$, 穂首節間長 $\left(\mathrm{X}_{2}\right)$ を説明変数, $\mathrm{R}\left(\mathrm{Y}_{1}\right)$ を目的変 数とした場合の重相関係数は $\mathrm{R}=0.584^{* * * *}$ であった．両 形質にかかる偏回帰係数は 1 穂籾数が負, 穂首節間長が正 であり，それぞれの寄与率は 47.8:52.2 と推定された（第 4 図). S $\left(\mathrm{Y}_{2}\right)$ を目的変数とし, 穂数 $\left(\mathrm{X}_{3}\right)$, 穂首節間直径 $\left(\mathrm{X}_{4}\right)$ ，成熟期の止葉角度 $\left(\mathrm{X}_{5}\right)$ を説明変数に用いた重相関 係数は $\mathrm{R}=0.539$ ***であった。 また，偏回帰係数はいず れも正で，それぞれの寄与率は $41.4: 34.9: 23.6$ であっ た（第 4 図）。これらより，第 4 表に示した重回帰式によっ て， $\mathrm{R}$ と S の品種間差は 30〜35\%程度説明できることが分 かった

\section{考察}

伊藤（1973）は，作物の多収性育種において選抜を行う

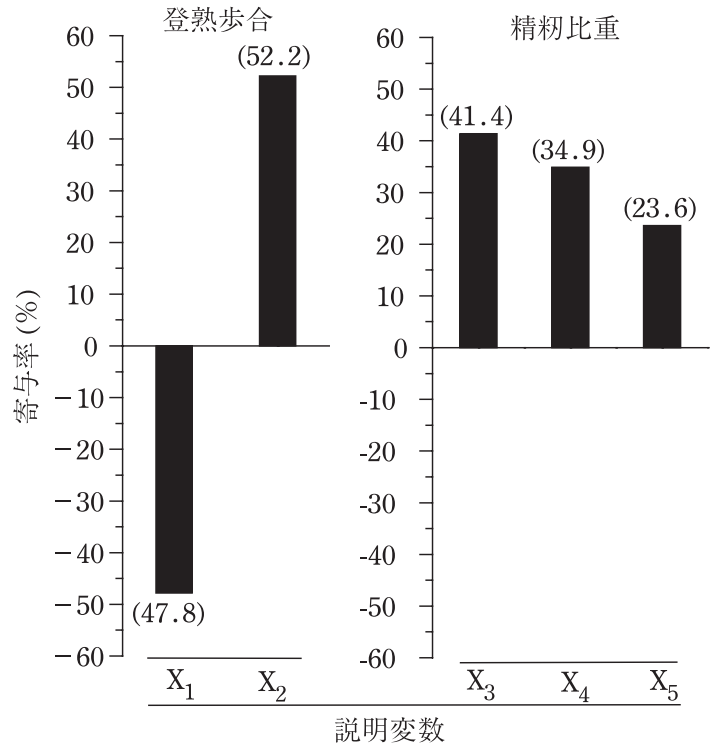

第 4 図 重回帰分析に打ける説明変数の寄与率.

$\mathrm{X}_{1}: 1$ 穂籵数, $\mathrm{X}_{2}$ : 穂首節間長, $X_{3}$ : 穂数, $X_{4}$ : 穂首節間直径,

$\mathrm{X}_{5}$ : 成熟期の止葉角度. 図中の（）は寄与率（\%).

場合の重要な要素として，作物生態学的にみて着目すべき 形質を決定すること，その形質の遺伝的安定性が高いこと， 着目する形質は測定が比較的容易であること，の 3 点を挙 げている，登熟性に対する選抜に関しても，同じことが言 える。すなわち，これまで報告（塩津ら 2006，2007）して きたように，登熟歩合や精籾比重には収量内容物／収量 キャパシティ比, 貯蔵炭水化物量, 炭水化物の転流, 維管 束特性などが関与するが，対象とする材料が多い選抜の初 期段階においてこれらを実測することは困難である。この ため, 選抜の初〜中期段階では観察や簡単な方法で調査で きる形態形質によって大まかな選抜を行い，数が絞り込ま れてくる後期段階から炭水化物などによる選抜を始めるの が現実的であると思われる。そこで，本試験では形態形質 と登熟歩合掞よび精籾比重との関係を調査し，形態形質に よって登熟性がどの程度評価できるか検討した。

試験に供試した中国品種 27, 日本品種 28, 印度型ある いは日印交雑型多収性品種 15 の登熟歩合の平均值は日本 品種が他に比べて有意に高く, 精籾比重は多収性品種, 日 本品種，中国品種の順に有意に高かった（第 1 表）。この 傾向は，これまでの試験結果（塩津ら 2006，2007）と一致 していた。一方，これまでの結果とは異なり，登熟歩合は 精籾比重と有意な正の相関を示した（第 3 図）。しかし， 
相関係数はそれ程高くなかったので，登熟歩合と精籾比重 は基本的に別々の機構によって決定されると判断した（塩 津ら 2006)

そこで先ず，出穂迄日数と登熟歩合抢よび精籾比重との 関係を調べたところ，登熟歩合との間に有意な相関関係は 認められなかったが，精粉比重とは有意な正の相関を示し た（第 2 図）。すなわち，登熟歩合に出穂期は影響してい なかったが，精籾比重は出穂期が遅い品種ほど高くなる傾 向を示した．また，形態形質と登熟歩合および精籾比重と の関係では，登熟歩合は 1 穂籾数， 1 次抒よび 2 次枝梗数, 草型指数, 粒着密度, 1 穂籾容積などの収量キャパシティ や穂の構造に関わる形質との関係が強く，精籾比重は出穂 期の葉面積指数, 成熟期の止葉角度, 出穂期㧍よび成熟期 の乾物重などの乾物生産に関わる特性との相関が強かった (第 2 表)。すなわち, 精籾比重は収量内容物に, 登熟歩合 はそれを受け取る収量キャパシティに強く影響される傾向 がみられた。また，登熟歩合と（成熟期の乾物重一出穂期 の乾物重)/総籾数との間にも有意な正の相関関係が存在し たが，これは登熟歩合には収量内容物/収量キャパシティ 比が強く関与するという著者らのこれまでの報告（塩津ら 2006，2007）と一致するものである，また，精籾比重と草 丈/程長比扔よび出穂期の乾物重との間に正, 穂重/全重 比との間に負の有意な相関関倸が認められたが, 䈳ら （1986）や平岡ら（1986）は草丈/稈長比が高いほど出穂期 の炭水化物含有率が高くなることを報告し, 村田（1976） は出穂期の乾物重によって貯蔵炭水化物量を代表すること ができると述べている，さらに，松村（2007）は穂重/全 重比が低い品種ほど出穂期までの貯蔵炭水化物量が多いと 指摘している。したがって，本試験に扔いてみられた草丈 / 程長比, 出穂期乾物重抒よび穂重/全重比と精籵比重と の間の相関関係は出穂期に扔ける貯蔵炭水化物量を介した ものと考えられる.すなわち, 草丈/程長比が高く, 出穂 期の乾物重が重く, 穂重/全重比が低い品種ほど出穂期ま での貯蔵炭水化物量が多くなるために精籾比重が向上する と推察される（塩津ら 2006，2007）。な扔, 出穂迄日数と 精籾比重との間に正の相関関係が存在したのも，晚生品種 ほど出穂期の乾物重が重く, 貯蔵炭水化物が多いことによ ると思われる（楠谷ら 1993，塩津ら 2006）。ただし，出穂 迄日数を固定した場合の草丈/程長比, 出穂期の乾物重, 穂重/全重比などと精籾比重との偏相関係数は単相関係数 より低くなった (第 2 表)。したがって, これらの関係に は出穂期が影響していると推測されるので，より詳しく解 析するためには早晚性を取り除いた検討が必要と考えられ た.

なお，登熟歩合は穂首節間長とも有意な正の相関を示し， 穂首節間長と草丈, 程長, 穂長, 止葉長, 止葉葉鞘長など との間には強い正の相関関係が認められた。このため，登 熟歩合には茎の大きさ，とくに茎上部の伸長性に関わる形 質も影響していると推測されたが，この関倸がどのような
機構によって成り立っているのかを本試験の調查内で明ら かにすることはできなかった，また，楠谷·三分一（1990） は, 本試験の結果とは逆に, 北海道の品種では穂首節間長 と登熟歩合との間に負の相関関倸が認められたと報告して いるが、この違いが供試した品種の差によるものか，ある いは環境条件の差によるものかについては，今後詳しく解 析していく必要があると思われる。

次に，調查した形質の中から代表的な形質を選び，それ ぞれを説明変数, 登熟歩合と精籾比重を目的変数とする重 回帰分析を行った，説明変数を選ぶにあたっては，調查が 比較的簡単で，登熟歩合および精籾比重との相関関係が強 く，かつ，それぞれの遺伝的結びつきが弱いことを基準と して検討し, これに基づいて 1 穂籾数, 穂首節間長, 穂数, 穂首節間直径，成熟期の止葉角度の 5 形質を選択した。出 穂期の葉色と精籾比重との単相関倸数は有意であったが, 出穂迄日数を固定した場合の偏相関係数に有意性は認めら れなかった (第 2 表)。このため, 早晚性が同じ品種間で は葉色と精籾比重は無関係であると判断されたので, 説明 変数には取り上げなかった。また，説明変数に選んだ 5 形 質のうち， 1 穂籾数と穂数および穂首節間直径との間には 強い相関関係が存在したが，他の形質相互間の相関係数は 低かった (第 3 表)。そこで, 登熟歩合に対しては 1 穂籾 数と穂首節間長を説明変数, 精籾比重に対しては穂数, 穂 首節間直径㧍よび成熟期の止葉角度を説明変数とした，登 熟歩合に対する重相関係数は $\mathrm{R}=0.584 * * *$ ，精籾比重に 対する重相関係数は $\mathrm{R}=0.539 * * * て ゙ ， と も に 0.1 \%$ 水準 で有意であった（第 4 表）。たたし，登熟歩合にかかる偏 回帰係数は 1 穂籾数が負, 穂首節間長が正, 精籾比重にか かる偏回帰係数は全て正であった．また，登熟歩合に対す る 1 穂籾数と穂首節間長の貢献割合は約 $9: 10$, 精籾比重 に対する穂数, 穂首節間直径, 成熟期の止葉角度の貢献割 合は約 $5: 4: 3$ と推定された（第 4 図）。な㧍, 先にも述 べたように，穂首節間直径は登熟歩合と負，精籾比重とは 正の有意な相関を示したが，1穂籾数の影響を取り除いた 場合の穂首節間直径と登熟歩合との偏相関係数が有意でな かったことから, 穂首節間直径は本来的に太い方が精籾比 重を通じて登熟性の向上に寄与すると判断した。

以上より, 穂数が多く 1 穂籾数の少ない穂数型で，しか も穂首節間が太くて長く，さらに止葉が大きく直立してい るという形態的総合特性に着目することで登熟性に優れる ものが選び取れる可能性が示された. ただし,これらによっ て登熟歩合や精籾比重の差を説明できる割合は 30～35\%程 度と考えられる。すなわち，この方法で真に登熟性が優れ るものを選抜出来る確率は $1 / 3$ 程度と推定されるが，こ の值を高いとみるか，低いとみるかは判断の分かれるとこ ろである。しかし，これらの形質の多寞や良否は観察や触 手によっても大略評価することが出来る，したがって，本 試験で得られた結果は, 多数の材料を扱う選抜の初期段階 に扔ける大まかな選抜指標としては役立つものと考えた。 
ただし, 本試験は気象条件が概ね平年並みに経過した年 (第 1 図）に行ったものであり，施肥量も比較的少なかった。 また, 本試験で行った解析は, 形態形質と登熟歩合あるい は精籾比重との相関関係を基にした現象論的なもので，本 質的な因果関係まで検討するには至っていない.今後は, 気象や施肥量などの栽培条件が異なる場合での検討を行う とともに, 形態形質と炭水化物の集積量やその転流との関 係を調査し, 本試験で得られた結果について検証していき たいと考えている.

\section{引用文献}

平岡博幸 · 寺島一男 - 西山岩男 1986. 多収性水稲品種の生理生態的 特性の解明 9）炭水化物の動態からみた多収性品種育成の目標形 質. 日作紀 $55: 17-18$.

Ichii, M. and H. Kuwada 1981. Application of ratoon to a test of Agronomic characters in rice breeding. I. Variation in ratoon ability and its relation to Agronomic characters of mother plant. Japan. J. Breed. $31: 273-278$.

Ichii, M. 1984. Studies on the utility of ratoon traits of rice as the indicator of agronomic characters in breeding. Memoirs of Faculty of Agriculture Kagawa University $44: 1-50$.

伊藤隆二 1973. 水稲育種における籾/わら比率による選抜に関する研 究. 農事試研報 $17: 1-59$.

小林陽 2004. 水稲の登熟期の再生量による登熟性の簡易選抜法. 育種 学研究 $6: 49-56$.

小松良行・金忠男 - 松尾喜義・片山信浩 - 片岡孝義 1984. 多収性外

国稲の品種生態. 四国農試報 $43: 1-37$.

楠谷彰人.三分一敬 1990. 水稲の冷温登熟性に関する研究. 第4報 登
熟関連形質に対する主成分分析. 日作紀 $59: 679-686$.

楠谷彰人 · 浅沼興一郎・木暮秩 1993. 水稲に扔ける多収性の品種生 態に関する研究. 第1報 収量構造の品種間差異. 日作紀 $62: 385-$ 394.

楠谷彰人·上田一好 · 浅沼興一郎・豊田正範 1999. 水稲に打ける多 収性の品種生態に関する研究ーソース・シンク比と収量との関係 -. 日作紀 $68: 21-28$.

松村修 2007. 飼料利用のための水稲茎葉部 NSC 蓄積の品種特性. 日 作紀 76(別 1): 50-51.

松島省三 1967. 稲作の理論と技術 - 収量成立の理論と応用-. 養賢 堂, 東京. $1-302$.

村田吉男 1976. 作物生産と栽培環境. 村田吉男 - 㺵村敦彦 - 石井龍一 共著, 作物の光合成と生態 - 作物生産の理論と応用 - . 農文協, 東 京. 147 - 196.

塩津文隆・劉建・豊田正範・楠谷彰人 2006. 水稲に打ける登熟性の 品種間差に関する研究一登熟に及ぼす収量内容物と収量キャパシ ティの影響一.日作紀 $75: 492-501$.

塩津文隆・劉建・豊田正範・楠谷彰人 2007. 水稲における登熟性の 品種間差に関する研究－登熟に及ぼす穂首節間維管束面積と炭水 化物転流量の影響一. 日作紀 $76: 262-272$.

武田和義 1983. 形質とは何か - 遺伝相関と誘導形質. 第 4 回基礎育種 学シンポジウム報告 $: 3-8$.

津野幸人・山口武視・牛見哲也 1990. 登熟抑制処理の水稲にみられ る粒重と玄米中のアンモニア濃度との関係. 日作紀 $59: 481-493$.

翁仁憲・縣和一・武田友四郎 1986. 水稲の子実生産に関する物質生 産的研究. 第 4 報 出穂期に打ける全炭水化物濃度の品種間差. 日作 紀 $55: 201-207$.

気象庁電子閲覧室. http://www.data.kishou.go.jp.（2007/6/10閲覧）

Studies on Varietal Difference of Ripening Ability in Rice-Relation of Morphological Characteristics to Ripening Ability- : Fumitaka Shiotsu ${ }^{1)}$, Jian Liu $^{1)}$, Jiabin Bian ${ }^{1)}$, Masanori Tоүота ${ }^{2)}$ and Akihito Kusutani ${ }^{2)}\left({ }^{1)}\right.$ Unit. Grad. Sch. of Agr. Sci., Ehime Univ., Matsuyama 790-8566, Japan ; ${ }^{2}$ Fac. of Agr., Kagawa Univ., Miki 761-0795, Japan)

Abstract : The relationships between morphological characteristics and ripening ability of rice were investigated with Chinese varieties, Japanese varieties and high-yielding varieties bred in Asian countries. Multiple regression analysis was performed to examine whether the ripening ability of rice can be estimated by morphological characteristics. The results demonstrated that the percentage of ripened grains $(\mathrm{R})$ was closely related to some characteristics associated with yield capacity and structure of spike. Specific gravity of winnowed rough rice (S) showed close correlations with characteristics associated with dry matter production. Morphological characteristics, e. g., number of grains per head $\left(\mathrm{X}_{1}\right)$, length of neck internode $\left(\mathrm{X}_{2}\right)$, ear number $\left(\mathrm{X}_{3}\right)$, diameter of neck internode $\left(\mathrm{X}_{4}\right)$, and, angle of flag leaf $\left(\mathrm{X}_{5}\right)$ were selected as explanatory variables. Multiple correlation coefficients of the analysis with $\mathrm{R}$ as the dependent variable and $\mathrm{X}_{1}$ and $\mathrm{X}_{2}$ as explanatory variables, and $\mathrm{S}$ as the dependent variable and $\mathrm{X}_{3}, \mathrm{X}_{4}$ and $\mathrm{X}_{5}$ as explanatory variables were both significant. Thus, the results demonstrated that the varietal differences of ripening ability could be explained about $30 \sim 35 \%$ by morphological characteristics. These results suggest that morphological characteristics used as explanatory variables in this study may be useful as the selection index of ripening ability at the early ripening stage of rice.

Key words : Morphological characteristics, Multiple regression analysis, Paddy rice, Percentage of ripened grains, Ripening ability, Selection index, Specific gravity of winnowed rough rice, Varietal difference. 